\title{
Hadhrami Cultural Identity in Bafagih's Fatimah
}

\author{
$1^{\text {st }}$ Sayidatul Ummah \\ Literature Department, Faculty of \\ Humanities \\ Universitas Indonesia \\ Depok, Indonesia \\ sayidatulummah28@gmail.com
}

\author{
$2^{\text {nd }}$ Christina Suprihatin* \\ Literature Department, Faculty of \\ Humanities \\ Universitas Indonesia \\ Depok, Indonesia \\ christina.sup@gmail.com
}

\begin{abstract}
Indonesia is a multiethnic country with diverse and rich cultures. The Hadhrami people belong to the second largest minority group who came to Indonesia through diaspora. The Hadhrami people's assimilation was best facilitated through religion [1]. Another form of assimilation was interracial marriages, which gave resulted in mixed-race offspring (Peranakan/Muwallad). Certainly, interracial marriages engendered issues related to cultural identity. A portion of the Muwallad population choose to preserve native Hadhramaut culture inherited from their ancestors, but another portion of the Muwallad opt to adopt the cultures and traditions of their birthplace, Indonesia. There are many examples of this social reality in Indonesian literature, including Fatimah (1938) [2], a drama written by Hadhrami author Hoesin Bafagih. This research aims to elaborate on the discussions pertaining to intergenerational differences of Muwallad identity in Fatimah. Textual analysis, particularly the method of close reading, was applied during this research. In addition, concepts of representation and cultural identity [3], [4] are applied in analyzing the text. The research concludes that the drama reveals generational differences in Hadhrami descendants' understanding and practice of cultural identity. Hadhrami people are heterogenous while being both inclusive and exclusive, and this heterogeneity is not entirely anchored by age. Instead of portraying Hadhrami youth as an inclusive group, Fatimah's inclusivity can be more clearly found in the portrayal of the older Hadhrami group.
\end{abstract}

Keywords-Hadhrami, Muwallad, Cultural Identity, Representation

\section{Introduction}

As a nation with 200 ethnic groups inhabiting more than 13,000 islands, Indonesia frequently articulates its diversity as its strength. Unfortunately, the spirit of diversity is not always reflected within the daily lives of many Indonesians. The resurging manipulation of issues pertaining to race and religion has led to more rigid segregation of the country's citizens. Derogatory terms and pejorative expressions are often used to refer to particular minority groups, including the Hadhrami.

The Hadhrami are a group of people formed by interracial marriages between migrants from the Hadhramaut region of the Arabian Peninsula and Indonesian women. Originally, Hadhramaut tradition forbade Hadhrami women from leaving their original birthplace. As Indonesian-born descendants of Hadhramaut migrants, the Muwallad (mixedrace offspring) live in converging identities even as they reconcile the need to preserve their Hadhramaut heritage and the demand to be a part of Indonesia. This condition results in a space of negotiation for Hadhrami people to balance out the two worlds and make them complementary to one another. However, at the same time, it also generates intergenerational conflicts within the Hadhrami people, particularly between older and younger Muwallads.

The conflict was particularly tangible when a group of youth, led by A.R. Baswedan, formed the Partai Arab Indonesia (PAI) (Arab-Indonesia Party) in 1934. The group stands on a foundation of recognizing Indonesia as its homeland, so PAI rejected not only Hadhrami nationality but also 'urubah (Arabian characteristics). The PAI's idea of Indonesian-ness was further marked by the Arab descendants' Youth Pledge (Sumpah Pemuda Keturunan $A r a b)$, which was dubbed by Ki Hadjar Dewantara as "the day of enlightenment" (hari kesadaran) for Indonesian brothers of Hadhrami descent [5]. The pledge immediately garnered criticisms from many groups as it was considered a cause for division among Hadhrami people and a travesty for the Hadhramaut identity of their ancestors. Al-jaum and AlMurshid were two newspapers that frequently criticized PAI, which was at the time dominated by young Hadhramis. Despite these rampant criticisms, PAI kept voicing its idea of Indonesian-ness [1].

The social phenomenon gained attention and responses from writers, particularly those with Hadhrami heritage. As a young member of PAI and a journalist, Hoesin Bafagih wrote a drama titled Fatimah in 1938. According to Bahanan in Hayaze' [6], Fatimah is a magnum opus that marks the peak of Bafagih's intellectuality. It is also important to note that Fatimah [2] was written to meet the request of PAI Semarang's chairman, who asked the play to be shown during the party's third congress. Compared to other PAIsanctioned works, Fatimah was indeed the most controversial play that the party had ever seen.

This article investigates issues pertaining to Hadhrami descendants' issues of cultural identity as portrayed in Fatimah. With the scarcity of literary works about Hadhrami people written by either Hadhrami or Indonesian writers, this literary analysis is a significant contribution to the discussion. While no case study research on Fatimah has been found, there is some extant research on the publication of the work. De Jonge [7] was found to have studied the Hadhrami people's response to Fatimah at the time the play was performed. Meanwhile, national and international research on Hadhrami people is dominated by sociological, anthropological, and historical approaches.

Recent research by Mahzumi [8] examined the unchanging nationalism of the Hadhrami people in an Arab Village (kampung Arab) in Gresik and found both continuity 
and discontinuity in the Hadhrami people's identity. In terms of religious and cultural practices, Hadhramaut tradition is still mainly grounded in native Hadhramaut culture, as commonly seen in kafā 'ah in marriages. On the other hand, for Hadhrami people in Gresik, nationalism is embodied in the education, religion, and love for Indonesia that they share with their children. While preceding research has discussed the Hadhrami people's issues through ethnographic and historical approaches, this research aims to discuss the same issue through a literary work. It is expected that this academic writing contributes to the discussion on Hadhrami people in Indonesia.

\section{Methods}

Textual analysis, particularly the method of close reading, is applied in analyzing Fatimah. In the analysis, the text's characterization is understood through the lens of Hall's [4] concept of representation, which is defined as the process of production and meaning exchanges as examined through language. Issues related to cultural identity are also analyzed through Hall's [3] concept of identity. In this concept, Hall [3] argues that identity is a solid construction (being) as well as a transformative process (of becoming) by referring to both the past and the present. This process of becoming constantly occurs and adjusts to particular sociocultural contexts, space, and place.

\section{Results and Discussions}

\section{Hadhramaut Culture and Marriage}

For the Hadhrami people, marriages are in the same sacred realm as births and deaths. Therefore, it is unsurprising to find that marriage is a social institution that tends to generate complexities within one's identity. Furthermore, in Hadhramaut traditions, marriage is not the unification of two beings for the sake of reproduction but a medium of preserving marwah as descendants of the Prophet [9]. More specifically, the fundamental aspect in Hadhrami people's traditional culture of marriages is $k a f a$ 'ah as related to issues of nasab (offspring). According to Bujra [10], Hadhrami people believe in an ascriptive social stratification that influences virtually all aspects of life, including marriages. In the system, a syarifah is only allowed to marry a man coming from either equal or higher social levels.

Fatimah tells the story of a Hadhrami man and his struggle with his daughter's marriage. Through the character of Nasir, Fatimah shows an example of the attempts to deconstruct the concept of kafa'ah within the Hadhrami people's concept of marriage. In the story, when Nasir grows old and becomes vulnerable to illness, he wishes to arrange a marriage between his only daughter, Fatimah, and a young Hadhrami man named Mochtar. However, Mochtar comes from a different social class. Nasir's wish leads to conflict as it is not considered appropriate for Hadhrami people and the cultural concept of kafa'ah/nasab.

NASIR: (Smiling joyfully) There's some truth in his words. I actually could not fathom why I chose Mochtar to be Fatimah's husband, considering him being an unrecognized, poverty-stricken young man-a man without a position among the society (p. 86-87).
Such contrast between social and financial statuses as conveyed in the quotation above shows a change in understanding kafa'ah tradition. The word "unrecognized" refers to Mochtar's nasab (bloodline) and its inferior position among Hadhrami people. In other words, Mochtar is not a man with a nasab equal to that of Fatimah. Nasir's decision to keep Mochtar as his daughter's soon-to-be husband proves that by putting forward principles of equality (which, in a sense, is contradictory to Hadhrami tradition), Nasir attempts to reconstruct the meaning of kafa'ah in Hadhramaut culture. Despite such a principle of equality in reinterpreting the concept of kafa'ah, in discussions about marriage, with the depiction of endogamous marriage, Fatimah does not entirely separate itself from conforming to the traditions of the Hadhrami people's ancestors.

NASIR: $\quad$ I will let my daughter marry Mochtar[...]I believe that he will guard Fatimah's fortune through the inheritance that I will leave behind, which he will take a part of (p. 91).

In the quotation above, Nasir emphasizes that one of his concerns in arranging a marriage between Fatimah and Mochtar is related to Mochtar's ability to provide for Fatimah. This is influenced by the underlying Hadhrami philosophy of marriage, in which endogamy will always bring happiness. According to Patji [11], endogamous marriages are more commonly found in later generations who were trying to preserve the Hadhrami community. Aside from preserving the purity of nasab and racial identity, endogamous marriages commonly occurring among Hadhrami people are often founded on beliefs and security of possessions [12]. In addition, endogamy is enforced since exogamous marriages will open up the possibility of a nonHadhrami spouse to know taboos or secrets of a Hadhrami family, and this is an assumed cause of divorces. In other words, for Hadhrami people, endogamy is not only loaded with cultural meanings but also something normative.

\section{Hadhramaut Culture and Economy}

The Arab-Hadhramaut society is well-known as people of diaspora who travel to and stay in different parts of the world. Economy is the most common factor that motivates them to travel abroad. Such a condition affects the Hadhrami people's work ethics in foreign lands, including Nusantara. As stated by Burton, "it is generally said that the sun does not rise upon a land that does not contain a man from Hadramaut" [13]. In addition, this also leads to a condition where Hadhrami people are identified with trading activities.

According to historical records, the trade pattern of Hadhrami people usually started with insignificant capital. As time went by, they would gather more capital while working as shopkeepers for established Hadhrami merchants before building their own business independently. Usually, they were agents buying imported goods from European firms, which would later be sold to Hadhramaut, Chinese, or Indigenous (pribumi) merchants. The goods were sold either wholesale or retail, cash or credit. Berg [14] found that it was not uncommon for Hadhramaut merchants to lend or give capital for their kin who wished to start a new business. In other words, although they lean on the individualistic pattern of trading, Hadhrami people also have a high sense of ethnic solidarity among themselves. 
This community was then considered the greatest competition to Chinese people in dominating any kind of market. Therefore, it is unsurprising to find cultural contacts through economic activities.

\section{MOCHTAR: What if we ran out of stock?}

MANSOER: We make a coalition! Make it two piles. We shall sell fragrance oil, powder, incense, and other goods with low price but great quantity (p. 127).

The quotation above shows that Mansoer initiates a negotiation of identity in the context of Hadhrami people's business ethics. That Mansoer chose trading as a solution for Mochtar is also a strategic action of preserving Hadhramaut identity, which is closely related to trading activities. Further significance of such identity can be found in the type of commodity that is traded: goods related to secondary needs, which require little capital but generate cash flow in the short term. At this point, Mansoer interpreted trading as a way of attaching oneself to their tradition.

However, upon further examination, the aforementioned scene also contains a new perspective of Hadhrami trading ethics at the time. Kongsi (coalition, company) is a business model based on capital gathered by two or more people and managed under mutual ownership. Hadhrami merchants, whose business is often built on individuality, rarely apply this business model. In the Dutch East Indies society, the word kongsi is identical to Dutch trading company, Vereenigde Oost Indische Compagnie, which was established with the purpose of monopolizing trade in Dutch colonial territories. In addition to this, Chinese people are more easily identified with the word kongsi. Puspitaviani and Rahayu [15] explained that among Chinese community, kongsi is a Chinese business model that is based on principles of family or brotherhood (p. 146-147). Compared to the previously discussed pattern of Hadhramaut trading activities, through the dialogue above, the text offers a new perspective on Hadhramaut trade. This also signifies openness in Hadhrami communities.

\section{Hadhramaut Culture and Education}

In Fatimah, education appears as a narrative that shapes the discussions on Hadhrami people's cultural identity. The text shows perspective differences between older and younger Hadhramaut generations in understanding education. Represented by Mochtar and Mansoer, the younger generation tends to understand education through the Hadhramaut worldview. Mochtar's choice of working as a teacher (instead of a wandering merchant) hints at a feeling of superiority over natives (pribumi) for occupying the second level of social stratification in the Dutch East Indies.

MOCHTAR: My brother! I certainly cannot do that. What an embarrassment-I have been accustomed to being a teacher, a profession to whom people pay great respect. Now we carry our goods and trade in and out of kampoengs [...] What will people say about me? (p. 128)
In the quotation above, the statement "in and out of kampoengs" indicates a feeling of superiority. As a secondclass citizen and a teacher in a colonial society, Mochtar does not oppose trade but refuses the offered trade model: selling retail goods as wandering merchants. At this point, the profession of a teacher represents Hadhrami people's attempt at distancing themselves from their other citizens while retaining a demand for respect.

Meanwhile, represented by Nasir, the older group has an opposite attitude. His views on teachers show that Nair represents openness from the older group of Hadhrami people. Choosing a teacher as his soon-to-be son-in-law, Nasir's action shows a sense of awareness about education as well as respect for teachers.

NASIR: You see, Mochtar...I have but one daughter, Fatimah. By now, you must be acquainted with her behavior and demeanor-you've been a teacher of her, haven't you? [...] this is why I want you to marry my daughter, Fatimah. I am very certain that fortunes will accompany both of you later in life. [...] (p. 94)

The quotation above shows how Nasir greatly respects teachers. As a father, Nasir wishes the best for Fatimah, who was the only daughter of a wealthy person. By choosing Mochtar, he trusts Fatimah's fate in the hand of a teacher. In Nasir's view, a teacher not only educates his students by giving cognitive, affective, and psychomotor training but also understands a pupil's psychological condition. In fact, teachers in Arab schools are expected to be skilled in both modern science and religious studies. It can be inferred that, according to Nasir, teachers certainly bring progressiveness for the people around them. In particular, Nasir believed that by marrying Mochtar, his daughter Fatimah would be blessed with fortunes in both her earthly life and afterlife. Thus, Nasir's perspective on teachers is positive. Although Nasir is a merchant himself, in his view, teachers occupy a very respectable social status.

\section{Conclusion}

In portraying intergenerational issues among Hadhrami people, Hoesin Bafagih's drama Fatimah depicts interpretations of cultural identity that are not only diverse but also both exclusive and inclusive. The text shows ambivalence to marriage; initially, it attempted to reconstruct the kafa'ah nasab tradition, but the attempt was reduced to endogamy. Instead of trying to appear fluid and open, Hadhrami descendants further reinforce their Hadhramaut characteristics through opting for an intra-ethnic marriage. Meanwhile, in the aspect of economy, Hadhrami people are found to be more flexible and fluid. They could adopt a culture of another ethnic group and later merge it with their own trading culture. In terms of education, members of the younger generation of Hadhrami still attempt to seclude themselves through feelings of superiority while retaining the positive values of Hadhrami traditions: sincerity and love for science. In contrast, the older generation tends to be more fluid and open. Placed within the context of early $20^{\text {th }}$ century, Fatimah can be understood as a text that offers 
solutions for intergenerational conflicts taking place among Hadhrami people themselves.

\section{ACKNOWLEDGMENTS}

This research is funded by DRPM-GrantHibah, PITMA B Universitas Indonesia

\section{REFERENCES}

[1] Kesheh, N. M. (2007). The Hadrami Awakening (Kebangkitan Hadhrami di Indonesia). Jakarta: Akbar Media Sarana.

[2] Bafagih, H. (1938). Fatimah. Jakarta: The Lontar Foundation.

[3] Hall, S. (1990). Cultural Identity and Diaspora: Identity: Community, Culture, Difference. Lawrence and Wishart.

[4] Hall, S. (1997). Representation Cultural; Representation and Signifying Practices. London: Sage.

[5] Algadri, H. (1984). C. Snouck Hurgronje, Politik Belanda terhadap Islam dan Keturunan Arab (C. Snouck Hurgronje, Dutch politics towards Islam and Arab descent). Jakarta: Sinar Harapan.

[6] Hayaze', N. A. K. (2017). Kumpulan Tulisan dan Pemikiran Hoesin Bafagieh Tokoh PAI dan Nasionalis Keturunan Arab (Collection of writings and thoughts of Hoesin Bafagieh, PAI figure and nationalist of Arab descent). Jakarta: Menara Center.

[7] De Jonge, H. (2009). In The Name Of Fatimah: Staging The Emancipation Of The Hadhramis In The Netherlands East Indies. The
Hadhrami Diaspora in Southeast Asia, 245-262. https://doi.org/10.1163/ej.9789004172319.i-300.82.

[8] Mahzumi, F. (2018). Dualisme Identitas Peranakan Arab di Kampung Arab Gresik (Dualism of Arab Peranakan Identity in Gresik Arab Village). Teosofi, 8(2), 406-432.

[9] Syahab, S. U. (1999). Tuntutan Tanggung Jawab Terhadap Ahlul Bait dan Kafa'ahnya (Responsibility towards Ahlul Bait and his Kafa'ah). Jakarta: Yayasan Nusantara.

[10] Bujra, A. S. (1967). Political conflict and stratification in Hadramaut-I. Middle Eastern Studies, 3(4), 355-375. https://doi.org/10.1080/00263206708700083.

[11] Patji, A. R. (1991). The Arabs of Surabaya: A Study of Sociocultural Integration (Australian University). Retrieved from https://openresearch-repository.anu.edu.au/handle/1885/111185.

[12] Rahmaniah, S. E. (2014). Multikulturalisme dan Hegemoni Politik Pernikahan Endogami: Implikasi dalam Dakwah Islam (Multiculturalism and Political Hegemony of Endogamous Marriage: Its Implication towards Islamic Da'wah). 22, 24.

[13] Weir, D. (n.d.). Hadhramis: The Great Entrepreneurial Leaders of Arabia. 10.

[14] Berg, L. W. C. V. D. (1989). Hadramaut dan Koloni Arab di Nusantara (Hadramaut and the Arab Coloni in Nusantara). Jakarta: INIS.

[15] Puspitaviani, S., \& Rahayu, S. (2015). Aktivitas Ekonomi Etnis Tionghoa di Tuban Tahun 1945-1959 (Chinese's Economic Activity in Tuban 1945-1959). Verleden, 3(2), 144-153. 